\title{
Cover Crops Influence Meadow Vole Presence in Organic Orchards
}

\author{
Michel R. Wiman ${ }^{1}$, Elizabeth M. Kirby ${ }^{1}$, David M. Granatstein ${ }^{1,3}$, \\ and Thomas P. Sullivan ${ }^{2}$
}

ADDITIONAL INDEX WORDS. living mulch, sweet woodruff, legumes, sandwich system

SUMMARY. Living mulch cover crops can improve soil health and build organic matter, yet their use in fruit orchards comes with a risk of encouraging meadow vole (Microtus pennsylvanicus), a rodent that can be destructive to fruit trees. Several living mulch cover crop species were assessed in an apple (Malus $\times$ domestica) orchard understory along with wood chip mulch and bare ground. Desired species characteristics were weed competitiveness, low growth habit, nitrogen fixation, and potential rodent repellency. Legume species included birdsfoot trefoil (Lotus corniculatus), medic (Medicago spp.), and subterranean clover (Trifolium subterraneum), which were planted in solid stands as well as mixtures. Nonlegume species included sweet woodruff (Galium odoratum), sweet alyssum (Lobularia maritima), creeping thyme (Thymus serpyllum), and colonial bentgrass (Agrostis tenuis). Meadow vole presence was evaluated in fall and spring with point-intersect and run-length measurements. A legume mix (medic, birdsfoot trefoil, subterranean clover, and colonial bentgrass) had the highest meadow vole presence, with no reduction under the "sandwich" system of tilling either side of the tree trunks while leaving a cover crop in a narrow strip with the trunks. The nonlegume mix [colonial bentgrass, sweet alyssum, creeping thyme, and fivespot (Neomophila maculata)] had similar results. However, the sweet woodruff (planted in the "sandwich" system) had significantly lower presence of meadow voles than the other living mulches. Wood chip mulch, cultivation, and bare ground control were all similar, with very low presence, indicating low risk of meadow vole damage. The results from the sweet woodruff suggest that we need more research on the potential to select living mulches that are nonattractive or repellent to meadow voles for use in orchards.

$\mathrm{C}$ over crops are gaining popularity in orchards and vineyards for their ability to improve soil health and increase biodiversity (Ingels et al., 1998). Apple orchards typically have a weed-free zone in the tree row to reduce competition and minimize habitat for rodent pests. In organic orchards, this is commonly achieved by cultivation, which can degrade soil health and organic matter, damage roots, and compromise future tree performance (Granatstein et al., in press; Merwin and Stiles, 1994; Sánchez et al., 2007). The U.S. Department of Agriculture (USDA) National Organic

Funding was provided by Organic Cropping Research special grant (United States Dept. of AgricultureCooperative State Research Education and Extension Service).

We thank Amos Kukes for extensive field support.

${ }^{1}$ Center for Sustaining Agriculture and Natural Resources, Washington State University, Tree Fruit Research and Extension Center, 1100 North Western Avenue, Wenatchee, WA 98801

${ }^{2}$ Applied Mammal Research Institute, 11010 Mitchell Avenue, Summerland, British Columbia, V0H 1Z8, Canada

${ }^{3}$ Corresponding author. E-mail: granats@wsu.edu.
Standards stipulate that soil health be maintained or enhanced in organic systems [7 CFR, 205.203 (USDA, 2000)], and cover crops offer one strategy for achieving this objective. Cover crops, especially when used as a living mulch, enhance soil organic matter and microbial communities, reduce soil erosion, alleviate soil compaction, and increase water retention in orchards (Oliviera and Merwin, 2001; Proebsting, 1958), and contribute nitrogen when they consist of leguminous species. However, cover crop biomass also creates a favorable habitat for rodent pests (Sullivan and Hogue, 1987), and legumes are known to be a preferred rodent food source (Thompson, 1965). Rodents, particularly meadow voles, feed directly on tree trunks and can girdle trunks of all ages, causing irreparable damage (Byers, 1984; Hansson, 1979; Sullivan and Sullivan, 2006). In a previous trial that included white clover (Trifolium repens) as an in-row cover crop (D. Granatstein, unpublished data), meadow voles actively fed on the white clover during the winter months, helping lead to its virtual disappearance after the second winter, thus curtailing the multiple benefits the white clover provided.

Management of the orchard understory can influence whether meadow voles become a problem (Merwin et al., 1999; Sullivan and Sullivan, 2006). Bare soil in the tree row inhibits meadow voles by minimizing habitat cover, and the "sandwich" system (Weibel et al., 2007), which tills the sides of the tree row while maintaining a narrow cover crop strip in the tree line, is hypothesized to discourage meadow vole activity. Wood chip mulch has performed well for weed control and tree growth in previous trials (Granatstein and Mullinix, 2008), but its impact on meadow vole activity was not monitored, thus discouraging adoption by growers due to the uncertainty of meadow vole damage. The groundcover, sweet woodruff, contains coumarin (Fern, 1997), a compound used in rodent poisons that is a potential deterrent to meadow vole feeding. Thompson (1965) found a related species, northern bedstraw (Galium boreale), to have significantly lower feeding preference compared with several grasses and legumes, including white clover. As part of a larger orchard floor management experiment, we sought to determine how in-row cover crop species ("living mulch"), wood chip mulch, and tillage on each side of the trunks (i.e., the "sandwich" system) would influence meadow vole presence relative to a bare ground control.

\begin{tabular}{llll}
\hline $\begin{array}{l}\text { Units } \\
\text { Units To convert U.S. to SI, } \\
\text { multiply by }\end{array}$ & U.S. unit & SI unit & $\begin{array}{l}\text { To convert SI to U.S., } \\
\text { multiply by }\end{array}$ \\
\hline 0.3048 & $\mathrm{ft}$ & $\mathrm{m}$ & 3.2808 \\
0.0929 & $\mathrm{ft}^{2}$ & $\mathrm{~m}^{2}$ & 10.7639 \\
2.54 & inch $(\mathrm{es})$ & $\mathrm{cm}$ & 0.3937 \\
27.3403 & inch/ $\mathrm{ft}^{2}$ & $\mathrm{~cm} \cdot \mathrm{m}^{-2}$ & 0.0366 \\
0.4536 & $\mathrm{lb}$ & $\mathrm{kg}$ & 2.2046 \\
1.1209 & $\mathrm{lb} / \mathrm{acre}$ & $\mathrm{kg} \cdot \mathrm{ha}^{-1}$ & 0.8922
\end{tabular}




\section{Materials and methods}

The research was initiated in a new 'Pinova'/M.7, East MallingLong Ashton (M.7 EMLA) apple block planted in Apr. 2005 at the Wenatchee Valley College teaching orchard in East Wenatchee, WA. Tree spacing was $5.5 \times 13 \mathrm{ft}$ (623 trees/ acre). Tree row plots were $5 \mathrm{ft}$ wide $\times$ $44 \mathrm{ft}$ long, each with six sample trees and guard trees at each end of the plot. On 26 May 2005, drive alleys were planted to a standard companion grass mix (Northwest Wholesale Inc., Wenatchee, WA) of 20\% 'Fiesta' perennial ryegrass (Lolium perenne), $50 \%$ sheep fescue (Festuca ovina), and 30\% chewing's fescue (Festuca rubra) at a rate of $30 \mathrm{lb} /$ acre and were mowed four to five times per season. The experimental design was a randomized complete block with five replicates. Orchard floor management treatments of the tree row included: 1) bare ground control (CTL); 2) wood chip mulch 4 to 6 inch depth (WC); 3 ) clean cultivation using a rolling cultivator [WW (Wonder Weeder ${ }^{\circledR}$; Harris Mfg., Burbank, WA)]; 4) living mulch legume $\{\mathrm{LML}$ [mix of birdsfoot trefoil, 'Afghan' black medic (Medicago lupulina), burr medic (Medicago polymorpha), 'Mt. Barker' subterranean clover, and colonial bentgrass]\}; 5) living mulch nonlegume [LMNL (mix of sweet alyssum, creeping thyme, fivespot, and colonial bentgrass)]; 6) the "sandwich" system legume [SWL (a $1.75-\mathrm{ft}$ tilled strip on each side of the tree line and a $1.5-\mathrm{ft}$ strip of living mulch in the tree line; same species as LML)]; and 7) the "sandwich" system nonlegume $\{$ SWNL [same tillage as SWL, planted with alternating plugs of the groundcovers sweet woodruff and corsican mint (Mentha requienii) every 6 inches between the trunks]\}. Cover crops were planted from seed (except for plugs in SWNL) once in May 2005. Living mulch treatments were mowed to a 4 -inch height every 2 to 3 weeks during each season with a string weed trimmer, primarily to control weeds. Weeds in the CTL plot were controlled with hand pulling and a string weed trimmer to cut them at the soil surface. The entire orchard floor was irrigated with sprinklers (R-10 rotators; Nelson Irrigation, Walla Walla, WA), generally using 9 -h sets every $4 \mathrm{~d}$, but scheduled with tensiometers to avoid overirrigating. Chicken manure compost was hand-applied around each tree at a rate of $34 \mathrm{lb}$ per tree, split into three applications per year $(208$ $\mathrm{lb} /$ acre total $\mathrm{N}$; estimated $92 \mathrm{lb} /$ acre $\mathrm{N}$ available in season of application). Pocket gophers (Thomomys talpoides) were controlled seasonally with mechanical traps to protect the young trees (Sullivan et al., 2001).

Additional cover crop species and cultivars were tested in small plots in a satellite trial consisting of two rows of trees in the same planting immediately adjacent to the trial described above.

Plots were established in May 2005 , with three replications in a randomized complete-block design. One row contained 21 different living mulch groundcover treatments (LM Satellite), with plots $3.0 \times 2.5 \mathrm{ft}$. Each plot extended from the trunks to the edge of the drive alley (half the "weed strip"). The treatments were pure stands of sweet alyssum, six subterranean clover cultivars, six medic cultivars, kura clover (Trifolium ambiguum), three birdsfoot trefoil cultivars, fivespot, creeping thyme, and colonial bentgrass, with a bareground control. A second row used the "sandwich" system (Sandwich Satellite) and placed the groundcovers (mostly from plugs) in the tree row between the trunks, with plots $10.5 \mathrm{ft}$ long $\times 1.5 \mathrm{ft}$ wide. The nine groundcover treatments were white clover, subterranean clover mix ('Clare', 'Mt. Barker', and 'Nungarin'), phlox (Phlox subulata), potentilla (Potentilla neumanniana), creeping thyme, ajuga (Ajuga reptans), veronica (Veronica repens), black medic, and bare-ground control.

Meadow vole presence was evaluated by evidence of meadow vole activity and meadow vole damage to the trees. Meadow vole surface runways, feeding, holes, or feces were counted using a $0.5-\mathrm{m}^{2}$ grid of 36 intersection points (Hansson, 1979) and were subsampled three times per plot (once per plot in Satellite rows). Surface runway length was measured in each $0.5-\mathrm{m}^{2}$ grid area using a flexible rope (Hansson, 1979). Sampling times were Nov. 2005 and Feb. 2006 (Year 1), and Oct. 2006 and Mar. 2007 (Year 2, main trial only). In Feb. 2006, trunk injury was assessed in the main trial by visually examining every tree in one replicate plot, and then 1 month later, examining every other tree in all five replicate plots. Tree injury was determined by inspecting and measuring the area of chewing damage to the trunk near where it meets the ground. Statistical analyses were conducted with SAS (version 8; SAS Institute, Cary, NC) using analysis of variance, and means were compared with Fisher's least significant difference test at $P<0.05$.

\section{Results and discussion}

Most of the cover crops established well and formed solid groundcover where they were planted. The corsican mint in the SWNL plots died within weeks, apparently due to diseased planting stock; thus, that treatment became solely sweet woodruff, which filled the trunk line area and beyond, but was contained by the tillage. Over the course of the study, the most competitive species predominated in each species mixture. The LML and SWL plots became a 1:1 ratio of birdsfoot trefoil to colonial bentgrass, and the LMNL plots became mostly colonial bentgrass with creeping thyme. Creeping thyme did expand in biomass and area after year 1 , but the competition by the colonial bentgrass limited its contribution to the stand. Sweet alyssum and fivespot did not reseed, and the medics and subterranean clover did not return after year 1 .

Meadow vole populations were at the peak of their normal 3- to 4year population cycle during year 1 (T. Sullivan, personal communication), providing favorable conditions for assessment of orchard floor management treatment impacts. By the end of year 2, the population had dropped dramatically and it was difficult to find signs of meadow vole presence in any treatment (Fig. 1). The point-intersect data and runlength data generally indicated the same treatment effects (Table 1). Living mulches (LML and LMNL) had the most meadow vole presence for both sample dates in year 1 , along with SWL (Table 1). SWNL (with the sweet woodruff) had significantly lower meadow vole presence than the other cover crop treatments, but greater than the CTL, WW, or WC plots (for run length). These results suggest that the "sandwich" system may not deter meadow voles just by 


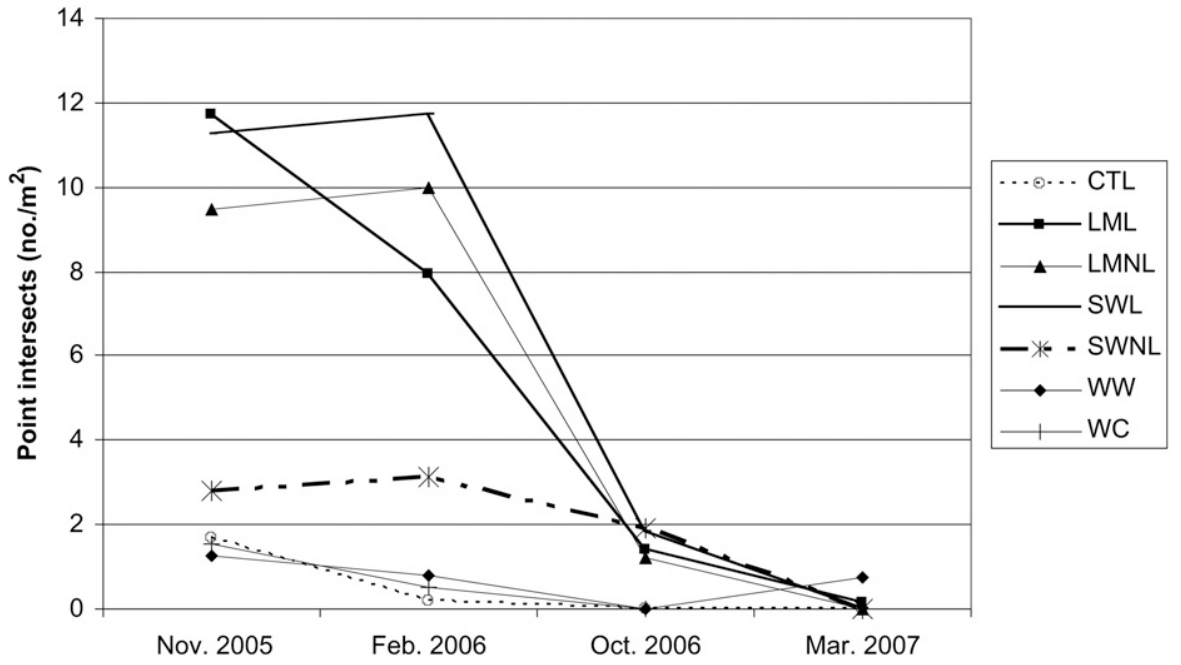

Fig. 1. Change in meadow vole presence in an apple orchard over two winters as measured by the point intersect method at East Wenatchee, WA (number of intersect points per square meter with meadow vole presence of 72 possible points; 1 point $/ \mathrm{m}^{2}=0.0929$ point $\left./ \mathrm{ft}^{2}\right)$. Orchard floor management treatments: CTL = bare ground control; WC $=$ wood chip mulch 4 to 6 inch $(10.2-15.2 \mathrm{~cm})$ depth; WW = clean cultivation using a rolling cultivator (Wonder Weeder ${ }^{\circledR}$; Harris Mfg., Burbank, WA); LML = living mulch legume (mix of birdsfoot trefoil, 'Afghan' black medic, 'Mt. Barker' subterranean clover, and colonial bentgrass); LMNL = living mulch nonlegume (mix of sweet alyssum, creeping thyme, fivespot, and colonial bentgrass); SWL = "sandwich" system legume [1.75 ft $(0.533 \mathrm{~m})$ tilled strip on each side of the tree line and a $1.5 \mathrm{ft}(0.457 \mathrm{~m})$ strip of living mulch in the tree line; same species as LML]; SWNL = "sandwich" system nonlegume (same tillage as SWL, planted with alternating plugs of the groundcovers sweet woodruff and corsican mint every 6 inches between the trunks).

Table 1. Evidence of meadow vole presence under different orchard floor management treatments in an organic apple orchard by surface runway length measurements, East Wenatchee, WA.

\begin{tabular}{|c|c|c|c|c|}
\hline \multirow[b]{3}{*}{ Treatment $^{z}$} & \multicolumn{4}{|c|}{ Sample date } \\
\hline & Nov. 2005 & Feb. 2006 & Oct. 2006 & Mar. 2007 \\
\hline & \multicolumn{4}{|c|}{ Surface runway length $\left(\mathrm{cm} \cdot \mathrm{m}^{-2}\right)^{y}$} \\
\hline LML & $297.3 a^{x}$ & $196.7 \mathrm{~b}$ & 51.3 & 0 \\
\hline LMNL & $188.0 \mathrm{c}$ & $286.0 \mathrm{ab}$ & 45.3 & 0 \\
\hline SWL & $264.0 \mathrm{ab}$ & $354.0 \mathrm{a}$ & 43.0 & 0 \\
\hline SWNL & $117.3 \mathrm{c}$ & $90.0 \mathrm{c}$ & 63.3 & 0 \\
\hline WC & $18.7 \mathrm{~d}$ & $17.3 \mathrm{c}$ & 0 & 0 \\
\hline CTL & $33.3 \mathrm{~d}$ & $4.0 \mathrm{c}$ & 0 & 0 \\
\hline WW & $5.3 \mathrm{~d}$ & $26.0 \mathrm{c}$ & 0 & 0 \\
\hline$P$ & $<0.001$ & 0.018 & 0.112 & \\
\hline
\end{tabular}

${ }^{2} \mathrm{CTL}=$ bare ground control; $\mathrm{WC}=$ wood chip mulch 4 to 6 inch $(10.2-15.2 \mathrm{~cm})$ depth; $\mathrm{WW}=$ clean cultivation using a rolling cultivator (Wonder Weeder ${ }^{\circledR}$; Harris Mfg., Burbank, WA); LML = living mulch legume (mix of birdsfoot trefoil, 'Afghan' black medic, 'Mt. Barker' subterranean clover, and colonial bentgrass); LMNL = living mulch non-legume (mix of sweet alyssum, creeping thyme, fivespot, and colonial bentgrass); SWL = "sandwich" system legume [ $1.75 \mathrm{ft}(0.533 \mathrm{~m})$ tilled strip on each side of the tree line and a $1.5 \mathrm{ft}(0.457 \mathrm{~m})$ strip of living mulch in the tree line; same species as LML]; SWNL = "sandwich" system nonlegume (same tillage as SWL, planted with alternating plugs of the groundcovers sweet woodruff and corsican mint every 6 inches between the trunks).

${ }^{\mathrm{y}} 1 \mathrm{~cm} \cdot \mathrm{m}^{-2}=0.0366$ inch $/ \mathrm{ft}^{2}$.

${ }^{x}$ Mean separation test in columns by Fisher's least significant difference at $P<0.05$

virtue of the bare ground it provides on either side of the cover crop because LML and SWL were not different. The choice of legume versus nonlegume species also made no difference in meadow vole presence in LML and LMNL. Physical cover (habitat) may have been more of a determining factor in this young orchard than food preference. Meadow vole presence was significantly lower in the sweet woodruff despite good physical cover, and direct feeding studies would be needed to determine whether the lower presence was due to a lower feeding preference, as reported by Thompson (1965). Commercial peppermint (Mentha $\times$ piperita) growers in the state have reported few meadow voles in mint fields compared with other crops (G. Colley, personal communication), but the corsican mint in this trial did not survive to provide any evaluation.

While sweet woodruff exhibited lower meadow vole presence than the other cover crops, we did measure more run length in this cover crop at both sampling dates in year 1 (nonsignificant for Feb. 2006) than in the noncover crop plots. Differences for the point-intersect data were much smaller. Meadow vole presence in WC was not different from the bare plots (CTL and WW), verifying previous observations by us and others of the low meadow vole preference for that material. Less than $2 \%$ of the trees sampled across the entire trial had evidence of meadow vole feeding on the trunks (data not shown).

In the LM Satellite row, seven of 21 living mulch treatments had signs of meadow vole presence in Feb. 2006 (data not shown). Only four treatments had measurable run length [three birdsfoot trefoil cultivars $\left(30-78 \mathrm{~cm} \cdot \mathrm{m}^{-2}\right)$ and 'Santiago' burr medic $\left.\left(80 \mathrm{~cm} \cdot \mathrm{m}^{-2}\right)\right]$, but differences were nonsignificant (data not shown). No evidence of meadow vole presence was found for any of the treatments for the Oct. 2006 sampling.

In the Sandwich Satellite row, point-intersect and run-length data indicated meadow vole presence for all treatments in Nov. 2005. Differences were significant for point intersects, but no clear pattern by species was evident (Table 2). Ajuga, creeping thyme, and veronica plots tended to have the least meadow vole presence then and in Feb. 2006, and were not different from the control. Although the results from the main trial and the Sandwich Satellite row cannot be statistically compared, the latter was directly adjacent to the last row of the main trial, and all part of the same orchard planting with the same management other than the treatments. The Sandwich Satellite row had tillage on both sides of its entire length, whereas the "sandwich" plots in the main trial were interspersed with plots with no tillage. 
Table 2. Meadow vole presence in $\operatorname{Sandwich}^{\mathrm{z}}$ Satellite row, organic apple planting in East Wenatchee, WA.

\begin{tabular}{lcccc}
\hline & Intersect points ${ }^{\mathrm{y}}\left(\right.$ no. $\left./ \mathrm{m}^{2}\right)$ & & \multicolumn{2}{c}{ Run length $\left(\mathrm{cm} \cdot \mathbf{m}^{-2}\right)^{\mathrm{x}}$} \\
\cline { 2 - 2 } \cline { 5 - 5 } Ground cover species & Nov. 2005 & & Nov. 2005 & Feb. 2006 \\
\hline White clover & $35.4 \mathrm{a}^{\mathrm{w}}$ & & 340 & 193 \\
Subterranean clover mix & $30.0 \mathrm{ab}$ & & 280 & 80 \\
Phlox & $22.7 \mathrm{abc}$ & & 260 & 133 \\
Potentilla & $20.0 \mathrm{abc}$ & & 200 & 73 \\
Creeping thyme & $13.3 \mathrm{c}$ & & 147 & 0 \\
Black medic & $12.7 \mathrm{c}$ & & 147 & 87 \\
Ajuga & $13.3 \mathrm{c}$ & & 140 & 0 \\
Veronica & $12.0 \mathrm{c}$ & & 133 & 0 \\
Control bare ground & $17.4 \mathrm{bc}$ & & 193 & 0 \\
$P$ & 0.05 & 0.18 & 0.08 \\
\hline
\end{tabular}

z"Sandwich" system has a $1.5 \mathrm{ft}(0.457 \mathrm{~m})$ strip of cover crop in the trunk line, and a $1.75 \mathrm{ft}(0.533 \mathrm{~m})$ tilled strip on each side of this.

Number of intersect points per square meter with meadow vole presence, out of 72 possible points; 1 point $/ \mathrm{m}^{2}=$ 0.0929 point $/ \mathrm{ft}^{2}$

${ }^{\mathrm{x}} \mathrm{l} \mathrm{cm} \cdot \mathrm{m}^{-2}=0.0366$ inch $/ \mathrm{ft}^{2}$

"Mean separation test in columns by Fisher's least significant difference test at $P<0.05$.

Therefore, if the tillage were to have any deterrent effect on the meadow voles, we would have expected to see it in the Sandwich Satellite row. We did not; in fact, overall run lengths were greater there than the treatments with the least meadow vole presence in Trial 1. There were few signs of meadow voles in these plots in Oct. 2006.

While a larger plot size and groundcover management that spanned multiple rows to create an orchard-level treatment area would be more desirable for a field study of meadow voles, our method was of the same scale of that used by Byers (1981) for detecting activity and sign of woodland voles (Microtus pinetorum). As reported by Hansson (1979), the method is sound for these indirect assessments of the presence of meadow voles, which is not a measure of populations. The trial was surrounded on three sides by a mature apple orchard that provided ample meadow vole habitat. We did not see any block effect for meadow vole presence that would suggest unequal meadow vole pressure on the plots from in-migration. The results from these trials reinforce the observation that the use of any living mulch in the tree row will elevate the risk of tree damage from meadow voles. None of the legume species or cultivars appeared to have a markedly lower attractiveness for meadow voles than others. Nonlegume species that provided ample cover also experienced meadow vole presence. The drop in meadow vole presence in the cover crops in year 2 can be attributed to the meadow vole population cycle, as the cover crops provided ample cover and had new tissue growth from the periodic mowing in both years. Sweet woodruff had significantly lower meadow vole presence than other cover crops, perhaps due to the coumarin contained in the plant tissue (Fern, 1997), suggesting a potential for repellency through choice of cover crop species. The ornamental plant japanese pachysandra (Pachysandra terminalis) exerted repellency to meadow voles that was linked to steroidal alkaloids in the tissue (Curtis et al., 2003). Weibel et al. (2007) use mouseear hawkweed (Hieracium pilosella) as the cover crop in their "sandwich" system in Switzerland, and that plant reportedly also contains a coumarin-like compound and has allelopathic properties (Wikipedia, 2009). Wood chip mulch was similar to bare ground for meadow vole presence, a finding that suggests wood chips be given more consideration as a mulching material. In contrast, growers have observed meadow vole presence with other mulch materials such as straw and weed fabric (S. Ela, personal communication). While little damage to trees was observed in these trials, even in plots with high meadow vole presence, the risk of injury from meadow vole activity is very real. The greatest risk would occur when a cover crop, a peak in the meadow vole population cycle, and a winter with prolonged, deep snow cover coincide. Economic losses from such a situation could be severe. Therefore, more targeted studies for controlling meadow vole populations in organic orchards are needed before further innovations in cover crop and living mulch use can be employed.

\section{Literature cited}

Byers, R.E. 1981. Field method for evaluation of rodenticides for control of Microtus pinetorum in apple orchards, $\mathrm{p}$. 77-85. In: E.W. Schafer and C.R. Walker (eds.). Vertebrate pest control and management materials: Third conference. ASTM STP 752. Amer. Soc. Testing Materials, West Conshohocken, PA.

Byers, R.E. 1984. Control and management of vertebrate pests in deciduous orchards of the eastern United States. Hort. Rev. (Amer. Soc. Hort. Sci.) 6:253285 .

Curtis, P.D., E.D. Rowland, M.M. Harribal, G.B. Curtis, J.A. Renwick, M.D. Martin-Rehrmann, and G.L. Good. 2003. Plant compounds in Pachysandra terminalis that act as feeding deterrents to prairie meadow voles. HortScience 38: 390-394.

Fern, K. 1997. Plants for a future. 7 Jan. 2009. <http://www.pfaf.org/database/ plants.php?Galium+odoratum $>$.

Granatstein, D. and K. Mullinix. 2008. Mulching options for Northwest organic and conventional orchards. HortScience 43:45-50.

Granatstein, D., M. Wiman, E. Kirby, and K. Mullinix. Sustainability trade-offs in organic orchard floor management. Acta Hort. (In press).

Hansson, L. 1979. Field signs as indicators of meadow vole abundance. J. Appl. Ecol. 16:339-347.

Ingels, C., R.L. Bugg, G.T. McGourty, and L.P. Christensen. 1998. Cover cropping in vineyards. Univ. Calif., Div. Agr. Natural Resources Publ. 3338.

Merwin, I.A. and W.C. Stiles. 1994. Orchard groundcover management impacts on soil physical properties. J. Amer. Soc. Hort. Sci. 119:216-222.

Merwin, I.A., J.A. Ray, and P.D. Curtis. 1999. Orchard groundcover management systems affect meadow vole populations and damage to apple trees. HortScience 34:271-274.

Oliviera, M.T. and I.A. Merwin. 2001. Soil physical conditions in a New York orchard after eight years under different groundcover management systems. Plant Soil 234:233-237.

Proebsting, E.L. 1958. Yield, growth, and date of maturity of Elberta peaches as 


\section{Research Reports}

influenced by soil management systems. Washington Agr. Expt. Sta., Pullman, Sci. Paper 1710.

Sánchez, E.E., A. Giayetto, L. Cichón, D. Fernández, M.C. Aruani, and M. Curetti. 2007. Cover crops influence soil properties and tree performance in an organic apple (Malus domestica Borkh) orchard in northern Patagonia. Plant Soil 292:193203.

Sullivan, T.P. and D.S. Sullivan. 2006. Plant and small mammal diversity in orchard versus non-crop habitats. Agr. Ecosyst. Environ. 116:235-243.
Sullivan, T.P. and E.J. Hogue. 1987. Influence of orchard floor management on meadow vole and pocket gopher populations and damage in apple orchards. J. Amer. Soc. Hort. Sci. 112:971-977.

Sullivan, T.P., D.S. Sullivan, and E.J. Hogue. 2001. Reinvasion dynamics of northern pocket gopher (Thomomys talpoides) populations in removal areas. Crop Prot. 20:189-198.

Thompson, D.Q. 1965. Food preferences of the meadow vole (Microtus pennsylvanicus) in relation to habitat affinities. Amer. Midl. Nat. 74:76-85.
U.S. Department of Agriculture. 2000. National Organic Program: Final rule. Fed. Regist. 65(246):80643.

Weibel, F., L. Tamm, E. Wyss, C. Daniel, A. Häseli, and F. Suter. 2007. Organic fruit production in Europe: Successes in production and marketing in the last decade, perspectives and challenges for the future development. Acta Hort. 737:163-172.

Wikipedia. 2009. Hieracium pilosella. 9 Feb. 2009. <http://en.wikipedia.org/ wiki/Hieracium_pilosella>. 